\title{
FIGURAS DE UMA POÉTICA DO ATOR NO CINEMA
}

\author{
Figures of a poetic actor in film \\ Rejane Kasting Arruda \\ Universidade Vila Velha - UVV
}

Resumo: Parte-se da noção de "figuras do objeto a", introduzida pela psicanálise na Filosofia da Arte, para postular o trabalho do ator de cinema como poética, na medida em que aponta para modalidades distintas desta figura. Analisam-se perspectivas desta operação em dois tipos de atuação (naturalista e estranhada), demonstrando como se dá a produção deste lugar de vazio chamado "a".

Palavras-chave: objeto a - ator - cinema

Abstract: It starts with the notion of "object a", introduced by psychoanalysis at Philosophy of Art to postulate the work of the film actor as poetic in that it points to different modalities of this figure. Analyzes prospects of this operation into two types of performance (naturalist and estranged), demonstrating how does the production of this place of empty called "a".

Keywords: object a - actor - cinema 


\section{Problema de Partida}

A hipótese de partida é que a atuação se caracteriza como poética, na medida em que figura o "objeto a". Encontramos o conceito de "objeto a" em teóricos de orientação lacaniana, como Regnault, Ranciere, Milner, Baudiou, Safatle, Dunker. Trata-se de um objeto sem imagem, que nos remete a um lugar de não inscrição na linguagem; uma falta, um vazio. Este conceito adquire extrema importância na teoria e na prática psicanalítica e é formalizado, em um primeiro momento, por Lacan, em seus "Escritos", no texto "Subversão do sujeito e dialética do desejo" (1960), e posteriormente em "O Seminário, Livro 10: AAngústia": "[...] esse objeto, que de fato é apenas a presença de um cavo, de um vazio, ocupável, nos diz Freud, por não importa que objeto, e cuja instância só conhecemos na forma de objeto perdido, a minúsculo" (LACAN, 1960, p. 170). O objeto a é um objeto "do qual não se tem ideia” (LACAN, 1974, p. 53). Este objeto estruturalmente está relacionado à presença do sujeito como desejante:

Ora, ele [o objeto a] é justamente o que resiste a qualquer assimilação à função do significante, e é por isso mesmo que simboliza o que, na esfera do significante, sempre se apresenta como perdido, como aquilo que se perde para a significantização [signifiantisation]. Ora, é justamente esse dejeto, essa queda, o que resiste à significantização, que se revela constituir o fundamento como tal do sujeito desejante (...). (LACAN, 1962-1963/2005, p. 193)

Ele é propriamente a "causa" do desejo no sujeito.

\begin{abstract}
Direi que o objeto a não deve ser situado em coisa alguma que seja análoga à intencionalidade de uma noese. $\mathrm{Na}$ intencionalidade do desejo, esse objeto deve ser concebido como a causa do desejo. Para retomar minha metáfora de há pouco, o objeto está atrás do desejo. (LACAN, 1962, p. 114-115)
\end{abstract}

De acordo com a nossa hipótese, é apontando para este objeto que a cena se estabelece como poética, abrindo espaço para a instauração do desejo de decifração no espectador, por implicar a sua condição de sujeito da falta. Sendo a obra figurada como objeto causa do desejo (objeto a), diante do deparar-se com este objeto, o espectador se depara também com o desejo de um "si mesmo que falta" por não haver "o" significante que represente a sua singularidade. A cena seria, portanto, também, uma figuração do sujeito enquanto falta.

Segundo Dunker, a arte aponta para o "objeto a", através de figuras, organizadas por ele, no artigo "Entre o Olho e o Olhar: Arte e Psicanálise" (2006). Dunker destaca como figuras do "objeto a": o excesso (inevitavelmente evidenciando que nada basta e, assim, apontando para o espaço estrutural da falta); a anamorfose (o deslocamento do olhar para um ponto, a partir do qual se passa a ver algo que antes não se podia ver de outros pontos); a deformação e o informe (que colocam em questão os limites da forma, apontando para uma borda, um limite, onde se depara com o vazio); o 
estranhamento ${ }^{1}$, a despersonalização e a descrença no olhar (espécie de "não acredito no que vejo"). Estas são as figuras organizadas por Dunker.

A nossa hipótese é que estas também estão presentes no ator de cinema quando, por exemplo, a dimensão do rosto em primeiro plano o deforma ou quando os encontros entre pedaços do corpo e o quadro produzem estranhamento. Percebe-se uma poética da imagem na medida em que o ator aparece como forma estranhada.

Em certas poéticas fílmicas, a presença do ator inscreve a ideia de "boneco" ou "máquina" - como em "Mouchette" (1967) e "Pickpocket" (1959), de Bresson. "Nada de atores. (Nada de direção de atores). Nada de papéis. (Nada de estudo de papéis). Nada de posta em cena. Mas o emprego de modelos, tomados da vida. SER (modelos) no lugar de PARECER (atores)", disse Bresson, (1979, p. 10). Por não suportar o vínculo com a representação que o ator imprime, Bresson opta por não atores, aos quais chama "modelos", com profissões e características específicas. Com o preceito "Modelos: Movimento de fora para dentro. Atores: movimento de dentro para fora", trabalha os gestos perfeitamente coreografados - o que faz jus ao seu amor à precisão: "Controlar a precisão. Ser eu mesmo um veículo da precisão" (BRESSON, 1979, p. 9).

Fundamentada na precisão coreográfica, a poética da atuação acaba por imprimir

1 No sentido freudiano: um "estranho-íntimo", algo que é reconhecível e não é ao mesmo tempo. uma articulação com o universo diegético: a rigidez da professora de piano, de "Mouchette", e as consequências que esta traz às crianças, desubjetivandoas, tornando-as objetos (bonecos) de um sistema rígido de educação, calcado na autoridade obsessiva; ou, ainda, o domínio do ofício no caso da profissão do protagonista de "Pickpocket": batedor de carteira. Nos dois casos, o filme imprime um automatismo no gestual dos personagens - que o fazem "sem a intenção", "sem pensar": "A teus modelos: 'Não penses o que dizes, não penses o que fazes'. E também: 'Não penses no que dizes, não penses no que fazes' (...) Suprime radicalmente as intenções em teus modelos" (BRESSON, 1979, p. 21).

Este automatismo gestual poderia ser articulado à supermarionete proposta por Craig ou à biomecânica meyerholdiana, ambas engendrando a ideia de máquina ou boneco. No entanto, apesar da ênfase na precisão da coreografia corporal ("sem intenção"), demandada por Bresson, é possível perceber a sua busca pela visualidade de algo enigmático "dentro". Não a construção do personagem cujo pensamento o ator evidenciaria (se o representasse), mas, algo que se passa em nome próprio e o modelo tenta esconder: "O importante não é que me mostrem, mas que me escondam e, sobretudo, aquilo que não se suspeita que está neles" (BRESSON, 1979, p. 11).

A abordagem de Bresson cria uma espécie de estética do vazio no trabalho de atuação. Trata-se de um "nada" que 
no cinema contemporâneo se demanda também dos atores. Talvez, possamos falar nisto como um material apontando para o lugar do objeto a? Esta seria uma possível modalidade de figuração do "a" específica da atuação? Quando se faz alusão a um espaço enigmático que Bresson quer imprimir, se aponta também para a fratura, vazio, hiância, limite da forma do pensamento, limite do que se recorta?

Bresson não queria a visualidade de uma "construção" subjetiva do ator. Ele associa o "ser ator" a meios de reprodução do teatro, em detrimento da "criação" no cinematógrafo. Para ele, existem "dois tipos de cinema: os que empregam os recursos do teatro (atores, posta em cena, etc.) e utilizam da câmera para reproduzilos; e os que empregam os meios do cinematógrafo e se utilizam da câmera para criar" BRESSON, 1979, p. 11). Na página seguinte, ele associa a figura do ator ao "terrível costume do teatro", e contrapõe a ideia de representação (simbolizada pelo "teatro" e pelo "ator") à ideia de "criação de uma escritura", advogando para si o direito de recusarse a reproduzir:

O cinematógrafo é uma escritura com imagens e sons (...) Um filme não pode ser um espetáculo, porque um espetáculo exige a presença em carne e osso. Porém, como teatro fotografado o cinema pode ser a reprodução fotográfica de um espetáculo. Contudo, a reprodução fotográfica de um espetáculo é comparável à reprodução fotográfica de uma tela ou de uma escultura. Mas a reprodução fotográfica do São João Batista de Donatello ou de A Moça do Brinco de Pérola, de Vermeer, não tem nem o poder, nem o valor, nem a precisão desta escultura ou desta tela. Não as cria. Não cria nada. (BRESSON, 1979, p. 12)

Ao invés do ator "representar" (dar o espetáculo), é preciso colocar-se vulnerável à relação com a direção que o desenha - enquanto algo no seu interno é capturado como enigma: "Entre eles e eu, trocas telepáticas, adivinhação" (idem, p. 11). Ou seja, um dos princípios que se pode extrair das proposições bressonianas para o trabalho da atuação no cinema é que este é constituído na sua relação com o dispositivo de captação da imagem, sob a demanda de uma direção. O ator que não abdica do ato de representar "está no cinematógrafo como em um país estranho. Não fala a língua" (ibidem, p. 13).

Qual será a língua do cinematógrafo? Para Bresson não se trata de naturalidade, mas de natureza. Por mais que o ator treine técnicas para o efeito naturalidade acontecer (e poderíamos elencar algumas, como a troca da fala interna pela externa para a fala advir como impulso, a visualidade do pensamento, a cotidianidade e divisão de foco, a escansão do tempo ou sobreposição de falas, a imprecisão e oscilação da oralidade), Ihe faltará, ainda, a natureza. O trejeito do Naturalismo, para Bresson, é falso: "Nada mais falso em um filme que esse tom natural do teatro que imita a vida e imprime sentimentos estudados" (BRESSON, 1979, p. 14). O que tem o 
modelo que o ator não tem? Parece que ele está falando de um afeto real, que se passa em nome próprio, na relação do atuante com o dispositivo - à margem da interpretação da personagem e representação de "seus afetos". O estudo do sentimento, do gesto e da intenção da fala pelo ator é, para Bresson, absurdo: "Encontrar o gesto mais natural ou uma melhor maneira de falar em detrimento de outra, é absurdo, não tem sentido no cinematógrafo" (idem).

Em outras poéticas, o traço da expressividade do ator, certa estilização quando a intenção da construção é dada a ver, está veiculada ao "efeito de teatral" ou teatralidade (o teatral como uma construção que se dá a ver) - como em "A Paixão de Joana D'arc", de Dreyer (1921). O surgimento da poética naturalista vem justamente lutar contra a visualidade evidente de uma situação de representação, inscrita na atuação romântica e melodramática, mas recuperada por outra via no Simbolismo e no Expressionismo. Aênfase na construção formal, a visualidade da intenção da forma, denota um efeito de "teatral" como artifício. O traço de exagero é aceito como uma poética e se pode pensar, mais uma vez, em uma modalidade específica de figuração do "objeto a": o excesso de afeto como algo que transborda a forma, apontando, portanto, para a sua borda e seus limites. Em outras poéticas, ainda, nos deparamos com a afirmação do estranhamento (brechtiano) ${ }^{2}$ no cinema

2 O estranhamento ou distanciamento implica um choque entre visualidades diferentes; uma relação de montagem que gera pensamento. $\mathrm{O}$ termo, desenvolvido por Bertolt
- como em "Uma Mulher é uma Mulher", de Godard (1961) ${ }^{3}$. Estes são traços em função de certo estilo e não à revelia.

Testemunha-se que se trata de poéticas diferentes e que os signos veiculados à atuação dependem de arranjos específicos. Uma estética da atuação bressoniana, quando seguida por cineastas contemporâneos como Bruno Drumont, comporta-se como um terreno fértil para perfilar signos da despersonalização. Enquanto no campo da poética cênica de Meyerhold, Craig, Decroux, Kantor ou Wilson, esta estaria fatalmente veiculada aos signos de uma exacerbação da teatralidade, no campo cinematográfico, soa em oposição ao "terrível costume do teatro" (vide proposições de Bresson mencionadas).

É importante perceber a presença massacrante da crítica sobre certo suposto "teatral" no cinema contemporâneo, seja em uma estética ou em outra e, especialmente, quando se demanda a atuação naturalista. Kusnet, na entoada de Stanislavski, escreveu que o ator não deve representar, mas, viver (1992): o ator deve imprimir a visualidade da vida "real" e não a visualidade da representação (cara a teatrólogos como Meyerhold, Barba, Grotowski, Wilson, Decroux, Kantor, Craig e tantos outros cuja poética acusa e necessita da estilização, denotando a

\footnotetext{
Brecht, norteou sua práxis teatral e serviu de baliza para formulações teóricas no Século XX, desembocando no que Lehmann formalizou como Teatro Pós-dramático.

3 Tomamos como exemplo o momento onde os dois protagonistas olham para a câmera e cumprimentam quem estaria os olhando (o espectador), trazendo para a cena a visualidade de um eixo extra diegético.
} 
construção cênica em seu discurso). Mas, da atuação naturalista, a visualidade do artifício deve ser banida, pois o espectador deve esquecer-se que está diante de um ator.

Se pensarmos na demanda de uma atuação naturalista contemporânea, que conta com a diluição dos efeitos de teatralidade, poder-se-ia dizer que é da tentativa de representação da personagem que o teatral advém, ou melhor, da tentativa do ator representar a sua interpretação da personagem. Ao representar a sua interpretação, o ator teatraliza (denota uma construção). E se tenta imprimir o afeto para "preencher" esta forma (que representa a sua interpretação da personagem), cai na poética do Melodrama (contra qual o Naturalismo luta). E aproximandose do melodrama (em detrimento da neutralidade), o ator gera a repulsa em cineastas que explicitamente demandam a não representação: "Nada de tom, nada de intenção. No cinema, o ator deve contentar-se em dizer o texto. Renunciar a mostrar que já o compreendeu. Nada representar" (Monod apud NACCACHE, 2012, p. 73).

O entendimento da atuação como representação está muitas vezes na bagagem do ator e o conduz ao esforço de compreensão das ações de um roteiro (para representá-las). Fiandose em um imaginário assertivo sobre a personagem (e no discurso sobre a diegese), ele corre o risco de reduzir a criação à tentativa de validação da sua hipótese sobre a personagem que se esforça por representar, abrindo mão da criação da escritura, ou seja, da cena passível de diferentes escutas, tessitura poética que aponta para os limites da imagem, "a", ponto de vazio onde se suspende a interpretação - responsável pela experiência estética.

Segundo a nossa hipótese, para conquistar o estatuto de arte, o trabalho do ator deve operar a produção deste objeto sem imagem ou inscrição na linguagem, apontando para o limite (da forma, do quadro, do humano) e estranhando, "anamorfoseando", etc. - dependendo da poética fílmica onde está enquadrado. Assim, seria preciso ver como as figuras deste "a" se constituem também quando o efeito de realidade alucina (atuação naturalista).

Levando-se em conta as demandas da atuação contemporânea, esbarramos na ideia de que se pode fazer alusão ao espaço do "a", através também de outras figuras, como "um pequeno insignificante" que a anteriori não representaria nada e poderia ser jogado fora; espécie de prótese, de "a mais" que ganha brilho na tessitura fílmica. Com este "a" seria possível estranhar em atuações onde a espontaneidade e naturalidade são exaltadas.

Atribuímos a importância deste problema à demanda do cinema contemporâneo emergente pela atuação naturalista de maneira a exigir que o ator dilua a teatralidade, ou seja, a visualidade do seu ato. Assim, acredita-se que o "a" 
pode se dar também em corpos "sujos" de pessoalidade e cotidianidade.

\section{O ator como poética (e não como representação)}

A imagem abaixo, de "Fausto" (Sokurov, 2011), evidencia a inscrição do ator na poética do quadro (cinematográfico). $O$ tratamento da cor alude à composição plástica e o sujeito-ator é impresso como desenho, que por sua vez estranha por sua perspectiva de morto-vivo, de pinturacoisa-viva. Mas, quando se assume o ar documental, com a câmera solta e quase sem luz, como na cena de "Uma Mulher sob Influência", de Cassavetes (1974), onde Peter Falk fala ao telefone? O ator também é desenho, em jogo com os limites do quadro, estourando-o a cada instante ao provocar os movimentos da câmera. Os vetores do movimento dos impulsos do ator (como coisa viva implicada na poética fílmica) criam oposição às bordas do enquadre fílmico. A poética se realiza a partir das relações entre ator e quadro, na medida em que o limite das bordas (forma) do segundo é posto em questão.

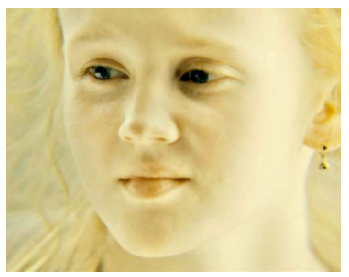

Figura 1: "Faust" (Sokurov, 2011)

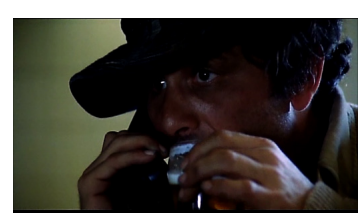

Figura 2: "Uma Mulher sob Influência" (Cassavetes, 1974)
Em outros dois exemplos - "Gritos e Sussurros" (Bergman, 1972) e "O Deserto Vermelho" (Antonioni, 1964) - vemos a inscrição do ator como pintura enquadrada por objetos ou anteparos que o velam: a porta em "Gritos e Sussurros" e a neblina em "O Deserto Vermelho".

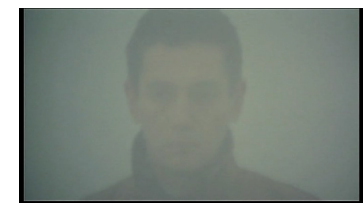

Figura 3: "O Deserto VermeIho" (Antonioni, 1964)

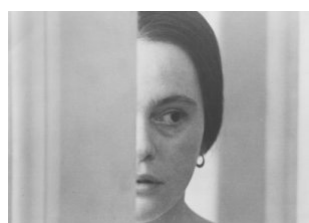

Figura 4: "Gritos e Sussurros" (Bergman, 1972)
Percebe-se um jogo entre o olhar do espectador e o velamento de parte do corpo (que fica de fora); um apontar para uma borda do olhar: o que não se pode ver. Como se o olhar tivesse brincando com o que cai para fora, o que se esconde, é elidido, velado, retirado. Este "algo" pode ser também o lugar do pensamento: espécie de "fora" que o buraco dos olhos situam.



Figura 5: "Pickpocket" (Bresson, 1959)

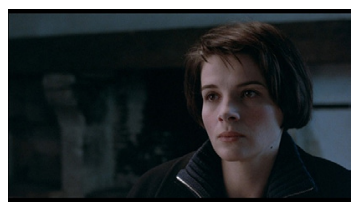

Figura 6: Juliette Binoche, em "A Liberdade é Azul" (Kieslowski, 1993)
No exemplo de Pickpocket (Bresson, 1959), temos a atriz Marika Green em uma espécie de resignação à imobilidade, deixando entrever a visualidade do pensamento. Este pensar pode, através da interpretação do espectador, ser introduzido a posteriori, na diegese, como pensar do personagem (apesar de enigmático, ele é suposto, adivinhado, 
na medida em que se coloca algo de si) tamponando-se o vazio da janela daquele olhar. Também sobre Juliette Binoche, em "A Liberdade é Azul" (Kieslowski, 1993), podemos dizer que algo vaza dos olhos, e se torna vivo, na medida em que se testemunha algum movimento interno. Algo se passa fora do campo de visão do espectador, neste fora que o buraco dos olhos situa. Concretamente, para o ator, pode ser uma imagem acústica ou visual segredada (voz que canta escondida e com a qual ele se encanta em segredo). O paradigma do desenho vivo está posto.

Quando se trata de imobilidade ou movimento estranhados, enquadra-se um desenho cuja visualidade pode implicar a escuta de significantes como "mortificado" ou "nada". Na dialética entre a morte e a vida, o trabalho do ator é construído implicando a memória corporal, esta tessitura de afetos que dilata o desenho, deformando-o, sujando-o - para imprimir o vivo (apesar do morto). Bresson lutava contra a "sujeira" do ator. No entanto, com as repetições dos vários takes, deveria ver a vida reluzir de repente, em um brilho que fazia "reviver o cadáver" (na metáfora de Leterrier).

A dimensão física desse trabalho avoluma-se com a exigência motivada pelo grande número de takes, que procuram captar o que só se deixa ver quando o ator se liberta de toda a tentação de investimento da personagem; e que esperam, segundo François Leterrier (Fontaine, em Fugiu um Condenado à Morte), "a expressão certa por acaso, como o médico debruçado sobre o moribundo espera a centelha de vida que diga que nem tudo está perdido". (NACCACHE, 2012, p. 73)

Em outras poéticas, o ator irrompe a carne encharcada de um excesso de afeto (lembrando que o excesso é uma das figuras do objeto a) e, neste caso, é preciso a erupção. Em outras, bastaria a tentativa forçada de se emocionar: caricatura, deboche, citação e artificialidade, caros a certos filmes. Seria necessário estudar caso a caso como a ideia de figura do "a" se articula em diferentes composições (neste caso, com a explicitação da artificialidade). Mas, existem aquelas poéticas onde é preciso secar para o brilho irromper de uma escuta escondida. A visualidade (plástica) do ator evoca o mundo ficcional, no entanto, não há um a anteriori "personagem" para se representar, pois a personagem é construída em montagem, evocada em pedaços no olhar do espectador, tal como um Frankenstein: tessitura de retalhos (significantes). Se a evocação ${ }^{4}$ depende da escuta e convoca a interpretação do espectador, é preciso marcar elementos específicos da poética onde o ator joga.



Figura 7: Emma Thompson e Dustin Hoffman, em "Tinha que ser você" (Joel Hopkins, 2009)



Figura 8: Nadine Nortier, em "Mouchette" (Bresson, 1967)




O jogo do efeito de realidade na atuação naturalista conta com a "cotidianidade", elemento específico desta escola (ou estilo) que deve se dar de maneira autônoma. O que quero dizer é que, para compor uma "personagem real", é preciso se ater a elementos da cotidianidade ao invés do esforço em representar a hipótese da interpretação sobre a personagem (sob o risco de fugir da poética naturalista). Os gestos "sujos" (imbuídos de pessoalidade), de Emma Thompson, em "Tinha que Ser Você" (Joel Hopkins, 2009), inscrevem uma poética de certa forma autônoma à ficção: a impressão de cotidianidade. A posteriori, pode-se ler: "ela é displicente" (por exemplo). Esta seria uma interpretação produzida pelo olhar do espectador. No entanto, se a atriz se esforçar para representar que a personagem é displicente, sairá do naturalismo e cairá na tipificação (contrária a esta poética). A cotidianidade de Thompson evoca algo poético para que a posteriori o espectador o interprete. É preciso deixar "o vácuo aberto". Há um jogo de evocações aos pedaços também nesta poética específica. Se os gestos mecanicizados, esvaziados, desubjetivados, podem evocar uma leitura de personagem "mortificada, subjulgada ao destino" (por exemplo), a atuação naturalista pode veicular outros significantes, como "simples, comum" ou "humano", interpretados pelo espectador conforme seu discurso, construção e desejo.

Em Amor e Morte (1967), Nadine Nortier é pura presença, mantida sob apertada vigilância por uma câmara que lhe proíbe qualquer efeito inoportuno. O seu corpo ambíguo, até na corrida desprovido de leveza adolescente, é regido por uma força superior: cada ação (não cantar, cantar, cuidar da mãe, atirar com terra às colegas) está separada de qualquer impulso, subtraída de qualquer iniciativa. Emudecida pela ação, mas privada do direito de reação, ela torna-se objeto inerte sob a fúria da professora que, para lhe arrancar uma nota certa, encosta-lhe rudemente o ouvido ao teclado do piano; a voz que então se eleva, límpida, é, como tudo o resto, imprevisível, mas a sensação de novidade logo se desfaz sob o efeito da repetição. (NACCACHE, 2012, p. 74)

Percebe-se que ambas as poéticas exigem do ator que deixe um espaço aberto, para que o espectador o tampone com a sua interpretação. Acreditamos que este seja um caminho para se pensar a poética da atuação realista na relação com a figura do objeto a: provocação do olhar, que precisa ser reelaborado, "anamorfoseado", para ver algo que, de um outro ponto de vista, não poderia ser visto (a provocação de um deslocamento do olhar do espectador na medida em que o ator é capaz de apontar para o vazio).

\section{Um "pequeno a mais" no "a" na atuação realista}

Naccache separa a presença do ator como pintura da presença de um "humano" - ao qual os diretores muitas vezes se opõem. Parece que, estruturalmente, a evocação do humano é algo diferente da plasticidade (seja imóvel ou móvel). O humano pode ser criado com a evocação da diegese (onde se situa a personagem com a qual 
o espectador se identifica) e a escuta de certos significantes. Parece que é preciso uma negociação, ou relação de equilíbrio com a plasticidade "fria" e "morta" da tela. "Frio e morto" criados também com a cotidianidade por esta implicar o automatismo. Equilíbrio que necessita, no entanto, ainda, da "naturalidade", que por sua vez depende da presença de um "insignificante":

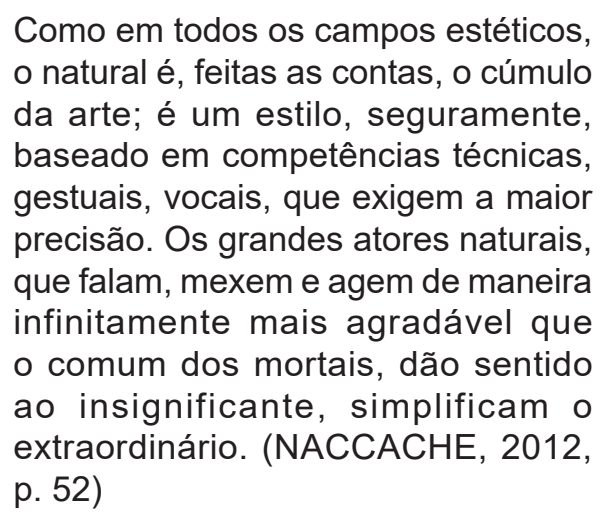

A significação já não tem importância, mas sim este mínimo, este pequeno que brilha. Assim, surge uma produção (poética) do corpo naturalista fundamentada no que não tem razão de ser: aquele "a mais" que não precisava, um "nadinha".

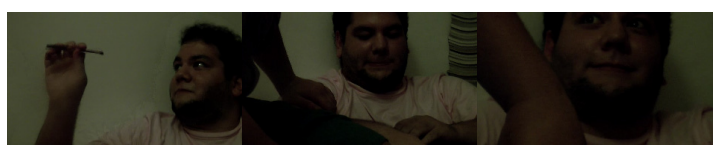

Figura 9: Henrique Neme, em oficina de Direção de Atores, na Academia Internacional de Cinema ${ }^{5}$

Uma brincadeira com a caneta transformada em aviãozinho; tensão nos lábios e bochechas gordas com certo olhar curioso: o que ganha a cena é o estilo, espécie de resíduo, que dá brilho. É a brincadeira com a luvinha de Brando, em "Sindicato de Ladrões" (Kazan, 1954) ou as rápidas piscadelas de Anna Karina, em "Uma Mulher é uma Mulher" (Godard, 1961). É neste sentido que o ator investe na construção de "um pequeno".

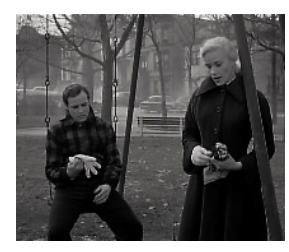

Figura 10: "Sindicato de Ladrões" (Kazan, 1954)

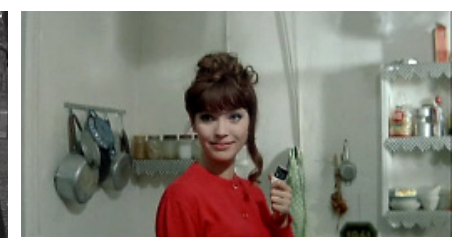

Figura 11: Anna Karina, em "Uma Mulher é uma Mulher" (Godard, 1961)
"É quando o ator acha que não fez nada que eu fico satisfeito" (STERNBERG apud NACCACHE, 2012, p.71). Sternberg, Hitchcock, Bresson, Pasolini: Naccache situa o ator como material da direção. "Quanto ao ator de cinema, é uma fabricação sintática, que se pode desfigurar com a luz, trair com a montagem, e a quem o cineasta pode a seu bel-prazer modificar o rosto e a voz" (NACCACHE, 2012, p. 70). O ator é plástico. Sobre Marlene Dietrich, em "A Imperatriz Vermelha” (Sternberg, 1934), diz:

A pele e o olhar de Marlene são puro receptáculo de luz. Um plano muito grande aprisiona-Ihe o rosto nas paredes do enquadramento, reduzindo-Ihe a representação aos únicos movimentos que o cineasta não pode impedir: os batimentos das pálpebras, o grau de abertura dos olhos, e a respiração que lhe ergue o véu numa palpitação imperceptível. (NACCACHE, 2012, p. 71) 
Mas, esta poética da imobilidade não quer dizer que a estrutura do trabalho do ator não esteja presente e que este ator não esteja trabalhando materiais (ocultos) ou a sua incidência - para sustentar a relação com limites tão estreitos. Não quer dizer que não haja ator vivo para evocar mortificação. Mesmo enquadrado pela imobilidade obsessiva (que serve à poética de um cineasta) - princípio que se encontra em Hitchcock ("os melhores atores são os eficazes mesmo quando não fazem nada") - é importante reconhecer a presença de materiais acústicos dos quais o ator lança mão (nem que seja a voz da direção rememorada). Isto para que se transmita uma perspectiva de manejo do jogo de composição e atuação - de construção de uma poética da atuação no cinema. "Não fazer nada", no enquadramento plástico-corporal imóvel (desenho do corpo), não quer dizer que não se utilize da alternância de materiais na escuta e no olhar, evocando, assim, o "atrás dos olhos". Apatia, aprisionamento e desubjetivação demandados: é por estar com algo "preso aos ouvidos" que se pode evocá-los. A atenção na escuta desfoca o olhar (perde-se o foco na imagem). Existe a construção que o diretor não se dá conta e que é trabalho do ator (pois este escuta e olha algo). O olhar e a escuta, como função, estão no jogo de sustentação do seu tempo (do tempo atoral) em cena.

No que se refere à poética da atuação, além da visualidade de algo que "se passa atrás dos olhos", há o que "aparece", cresce, no corporal, nas entrelinhas das palavras, e que dá brilho à cena: há produção de formas. A perspectiva que se abre: evocar a ação (que surge na diegese) depois da forma (do ator). Isto implica um efeito de anamorfose, pois estabelece o deslocamento do olhar para se enxergar algo depois; inclusão a posteriori "do pequeno", na poética da narrativa. Se, como ator, eu produzo algo (seja um desenho na imobilidade ou um "pequeno a mais") é "só depois" que o espectador pode inseri-lo na lógica da ficção, interpretá-lo e oferecer um olhar a ele, enquadrando-o (um olhar deslocado de onde estava quando não podia dar sentido a este elemento).

\section{Efeito de Alucinação: A Desconfiança do Próprio Olhar}

Vamos agora para as técnicas do ator; para os procedimentos velados; para o que o diretor e o espectador não vêm; e que, elidido do discurso cinematográfico, suporta a inscrição da sua presença como elemento da poética. O "não fazer nada" só pode estar sustentado por escuta e visualidade fabricadas no seu contexto em substituição à diegese, operação que Uta Hagen testemunha. É preciso apoio para "não fazer nada" no dispositivo de atuação, ou evocar a subjetividade da personagem viva e sucessivas ações internas. Tanto na evocação da morte (boneco, modelo, máquina) quanto do humano vivo (enquadrado na relação com o diegético) há produção atoral subjacente que Hagen chama "substituição". Na escola stanislavskiana, através do conjunto de procedimentos nos EUA reconhecido como "Método", a 
poética da atuação imprime a evocação de um cotidiano diegético. Os materiais que o ator utiliza para gerar um efeito de personagem são conduzidos por intensa elaboração verbal e visual (através de descrições). $O$ ator produz material extratexto falado. Assim, não representa o texto que está no roteiro, mas constrói materiais para a criação de uma cadeia de ações que entra em relação com este, acrescenta algo que produz uma terceira coisa. Se não for assim, paradoxalmente, por não usar o mecanismo cotidiano de pensar uma coisa e dizer outra, a fala surgirá teatralizada e imprimirá a situação de representação. Para produzir o efeito de inscrição no cotidiano, as ações são criadas a partir de impulsos que advém de materiais ocultos - em escuta ou visuais. Estes podem estar em foco durante toda a permanência do ator no dispositivo; ou ter marcado antes o seu corpo (de impulsos para ações) não estando mais em escuta. Ao mecanismo de situar no foco de atenção em algo que advém da própria história de vida para produzir uma catarata (sequência) de ações internas, Uta Hagen chama "substituição".

Temos que fazer essa transferência, essa descoberta do personagem, dentro de nós, por uma série contínua e sobreposta de substituições, a partir de nossas próprias experiências e lembranças, pelo uso da extensão imaginativa das realidades, e colocá-las no lugar da ficção da peça. (HAGEN, 2007, p. 51-52)

São elementos elididos do discurso fílmico e manejados pelo ator para que a sua presença imprima um espaço de defasagem entre interno e externo (novamente espaço vazio e enigmático para o qual se aponta e exige decifração).

O homem é um vivente com palavra. $E$ isto não significa que o homem tenha a palavra ou a linguagem como uma coisa, ou uma faculdade, ou uma ferramenta, mas que o homem é palavra, que o homem é enquanto palavra, que todo humano tem a ver com a palavra, se dá em palavra, está tecido de palavras, que o modo de viver próprio desse vivente, que é o homem, se dá na palavra e como palavra. (BONDIA, 2002, p. 21)

O corpo detém a tessitura de memória impregnada de linguagem na medida em que somos transpassados por palavras. Assim, é também com palavras que o ator aciona sua tessitura corporal e marca lugares de impulsos internos que o ajudam a sustentar sua presença, preparando o que em cena soará como natural. Conforme a palavra que utiliza subjacente em "substituição" (HAGEN, 2007), provoca ação - e a relação destas ações com a fala gera uma terceira coisa: a visualidade de um espaço. Apesar dos exemplos não dimensionarem a força que têm sobre determinado ator (graças a sua singularidade), vale a pena citálos, pois testemunham o mecanismo da substituição.

Manuela deve reagir com profunda vergonha e humilhação. A atriz não conseguia tornar esse momento significativo. Nem a roupa nem a atriz no papel da professora pareciam importar muito para ela. Por acaso, eu Ihe sugeri uma estimulante substituição para a professora e a camisa. Eu disse: 
"E se Lynn Fontainne tivesse nas mãos calcinhas manchadas e as mostrasse a você?" A atriz ficou vermelha como pimentão, arrancou a camisa das mãos de Fräulein Von Bernberg e a escondeu freneticamente atrás de si. (HAGEN, 2007, p. 52)

"E se Lynn Fontainne tivesse nas mãos calcinhas manchadas e as mostrasse a você?": a fala entra no foco de atenção da atriz, produzindo a ação "envergonhar-se". Assim, espontaneidade (e naturalidade) são efeitos de uma construção, de um manejo da estrutura do trabalho. Assim, se produz uma realidade que alucina, causando descrença do olhar por parecer real, por emprestar o "efeito de real" para aquilo que sabemos que é artifício.

Uso a substituição para 'fazer crer' no sentido literal para me fazer acreditar no tempo e no lugar que me rodeiam, nas forças condicionantes, em meu novo personagem e em minha relação com os demais personagens, para me colocar na ação espontânea imediata (...). (HAGEN, 2007, p. 52-53)

\section{Do Informe à Forma (da Ação)}

Passam-se por impasses e questões bem definidas - que retornam: "Em cena, o ator precisa escutar a fala interna?" Pode-se arriscar: "Não", pois é criada para consolidar os impulsos (estes que fragmentam a linha contínua do roteiro e da fala externa), e se estes já estão impregnados na memória, não é necessário situá-la novamente na escuta em cena". Fica mais ou menos claro que a fala interna é como uma mosca, que pousa na pele e voa, deixando o lugar marcado (a sensação das suas "patinhas"). Passa, marca um lugar de ruptura (da cadeia contínua do texto) e vai embora, deixando-o vazio para que o ator o preencha com a nova produção: a inscrição, em cena, de ação.

Em certos momentos é realmente isto. Mas, em outros, é preciso escutar imagens acústicas inventadas na hora. Qual a necessidade de se produzir antes falas internas se vamos trocá-las? 0 resíduo da anterior se faz presente na tessitura do corpo. Material de um arranjo complexo, serve para deslocar (estrada de materiais em sucessão) até que se chegue àquela que sustentará a escuta em cena. É inevitável abandonar uns para outros terem lugar. O movimento de procurar falas internas em cena imita o mecanismo do pensamento na vida, de palavra em palavra, onde não existe um antes a ser expresso, pois é no passo a passo do titubeio (ou na certeza de uma obsessão) que é construído.

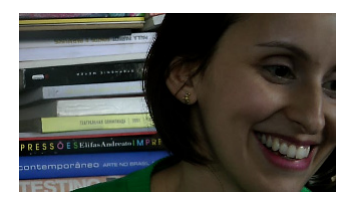

Figura 12: Juliane Pimenta, em cena com texto de "O Filho da Noiva" (Juan José Campanella, 2001)

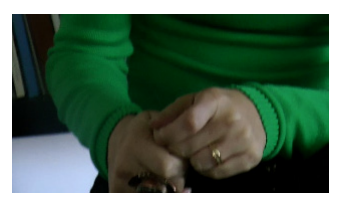

Figura 13: Juliane Pimenta, em cena com texto de "O Filho da Noiva"(Juan José Campanella, 2001)
O trabalho com a atriz Juliane Pimenta ${ }^{5}$ trouxe um desdobramento do uso de fala interna ${ }^{6}$. A atriz partira da interpretação da $5 \mathrm{Em}$ uma das oficinas de atuação para cinema ministrada pela autora.

60 termo encontra-se inicialmente em Eugênio Kusnet, em referência a uma redução do monólogo interior stanislavskiano: o ator vai tirando palavras do monólogo interior durante os ensaios, até ficar com uma delas apenas. 
personagem. As escolhas imprimiram a representação, com a reafirmação da dor, a angústia das carências que a personagem estaria sentindo. Começamos a trabalhar o contexto da Juliane: se havia errado na receita do bolo ou esquecido onde colocou as chaves, a atriz incluía este texto nas falas internas, interrompendo o fluxo do texto-dado (roteiro) com "distrações". Houve uma espécie de descolamento: as falas internas implicaram um contraponto ao drama da personagem. A atriz situou, em escuta, também uma música, que dividiu o seu foco de atenção, assim como o movimento dos dedos das suas mãos, criando sucessivas escansões (espaços) no tempo da fala (espaços preenchidos com a visualidade do seu pensamento impressa pela escuta da música) e pequeninas ações. A impressão de que a fala vai surgindo espontânea adveio com o novo arranjo.

Cantarolar em silêncio é um modo eficiente de ser valer do manejo deste lugar de escuta interna. A música vem em substituição à fala quando o ator tem dificuldade de criar palavras. No segundo momento, esta canção pode virar demanda: "Eu quero isso", "Cala a boca", "Mas por quê?", "Tá certo então". Neste lugar, onde a música interna se situa, pode-se imprimir o eco de "Por que não? Me diz!": a fala interna como demanda sobre o outro (uma das modalidades possíveis). E, ao alternar falas internas diferentes, criam-se ações que se revezam - uma funcionando como o contraponto da outra. Quando detalhamos a fala interna (uma para cada frase externo-falada) ou as sequenciamos para um momento de silêncio, surgem trocas e impulsos sequenciados. Tornase possível assim construir movimento interno, impresso no filme através do ator, espaço vazio que se mexe à espera de decifração. A fala cotidiana não é regular, mas de ritmo quebrado cheia de descompassos - causando um instante pela espera da síntese. As ações surgem deste "mar" de subtexto, em meio às ondas. Trata-se de dilatar ou interrogar limites da forma, pois dentro de um informe se provoca a aparição da forma da ação. O ator situa na escuta o material que o espectador não vê (interno) para provocar a tessitura corporal que atualiza vibrações preenchendo o enquadramento plástico-corporal na medida em que a relação com o outro está em jogo. Assim, cria a ilusão da sua "verdade" em cena.

No momento em que palavra ou ação se oferecem ao olhar, aparecem como espontâneas porque se trata de troca repentina, salto, revezamento imprimindo impulsos. O material interno produz descolamento do apoio que estaria no externo e a impressão de que este é espontâneo, inventado na hora (pois estamos livres para variar o tempo de enunciação e as trocas entre interno e externo, focando em um material e lançando um outro no espaço descoberto). O mimético cotidiano necessita deste efeito. A presença de impulso, aliada à cotidianidade que circunscreve o "natural" da atuação naturalista, permite um efeito de alucinação (como uma das figuras do "a") e a descrença no olhar. 
Elencam-se materiais com os quais o ator pode trabalhar a cotidianidade - e construir o efeito de "natural" se estes outros (troca, impulso) também se inscreverem: a distração com o corpo; a distração com o corpo do outro; a distração com o ambiente; as variações do movimento do olhar; as variações dos movimentos da boca; a variação do volume da voz (baixo, sussurrado); divisão da frase (escansão, aceleração); construção da música da fala; respiração; tempo-ritmo; atividades cotidianas. Estes materiais são "externos" por implicar o desenho das bordas do corpo ou da voz (o que aparece para o espectador). O ator divide o foco de atenção entre estes e aqueles internos. Assim, está apoiado "nas duas pernas" e pode sustentar o tempo de sua permanência no quadro. $A$ inscrição de um dos materiais serve como contra-impulso (oposição) à inscrição de outro. A ilusão de espontaneidade é criada em cada nova inscrição de novo material na cena do corpo, com pequenas variações que se pode extrair quando existe apoio oculto - imperceptíveis apoios: na imagem interna; na fala interna; na música interna. Quando o externo não está imbuído da cotidianidade, mas da imobilidade (plasticidade mórbida), a presença de material pode implicar efeito de vida (movimento) apesar da mortificação. Conquista-se equilíbrio: um pouco de humanidade na casca estática mascarada; efeito de obra que tematiza a forma e seus limites (mesmo a forma do humano e seus limites).

\section{A Irrupção do Afeto como Figura do Excesso e a Subversão como Princípio}

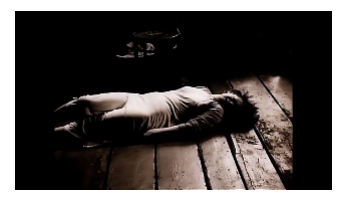

Figura 14: Alisa Frejndlikn, em "Stalker" (Tarkovski, 1979)

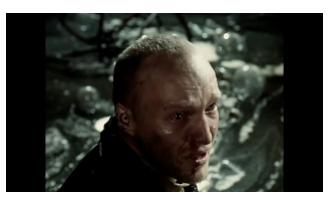

Figura 15: Aleksandr Kajdanovsky, em "Stalker" (Tarkovski, 1979)
No início de "Stalker" (Tarkovski, 1979), a cena em que a mulher se deixa cair é perturbadora. Descontroladas, as lágrimas caem do rosto contorcido de dor: o homem chora. O foco do ator não poderia estar na tentativa de chorar, mas no segurar a emoção que irrompe descontrolada. Tomamos a análise da "Memória Emotiva", termo advindo de Stanislavski, que gera impasses, transmitido como falência, pois o teatrólogo teria revisado a perspectiva do apoio na emoção. No entanto, não se trata de focar na emoção, mas, na associação escondida, na medida em que se opera por substituição: "Memória emotiva ou lembrança emotiva trata do problema de encontrar uma substituição para provocar a explosão de lágrimas, o grito de terror, o ataque de riso, etc." (HAGEN, 2007, p. 68). O material pode ser produzido nos bastidores, no contexto do dispositivo (e fora da diegese) para que o ator dele se aproprie (algo que sem querer apareceu e serve). Na filmagem de "Aquele Querido Mês de Agosto" (Miguel Gomes, 2008), para a atriz "cair na risada" (ação que, no filme, imprime verdade e, ao mesmo tempo, estranha, evocando contradição), alguém faz sinais atrás da 
câmera: bobagens ${ }^{7}$.

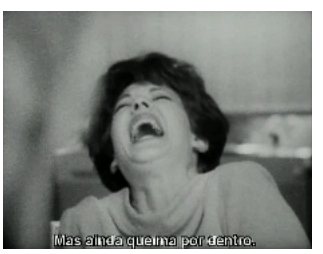

Figura 16: Lynn Carlin, em "Faces" (Cassavetes, 1968)

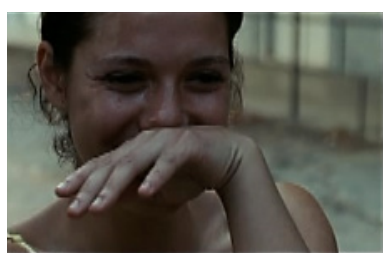

Figura 17: Sónia Bandeira, em "Aquele Querido Mês de Agosto" (Miguel Gomes, 2008)
É neste sentido que o ator se utiliza de material do próprio contexto: a memória emotiva está no contexto da experiência. A ação é inscrita na ficção e escutada, lida, interpretada, pelo espectador, "como se fosse" da personagem: um jogo de evocação a partir da "situação de set" (onde vive a atriz). Seja rememorando ou trazendo para o manejo algo dos bastidores, trata-se da apropriação do próprio contexto para se autoprovocar. Suspende-se a representação quando se desafia o ator a investir na verdade da sua atuação - em ato. É preciso marcar que cada processo é ato de ruptura com o antecedente, no sentido que os psicanalistas dão a palavra: "ruptura, intervalo não antecipável” (DUNKER, 2006, p. 33).

Grande foi a sensação do beijo; Capitu
ergueu-se rápida, eu recuei até a
parede com uma espécie de vertigem,
sem fala, os olhos escuros. Quando
eles me clarearam vi que Capitu tinha
os seus no chão. Não me atrevi a dizer
nada, ainda que quisesse faltava-me
língua. Preso, atordoado, não achava
gesto nem ímpeto que me descolasse
da parede e me atirasse a ela com mil

7 Fala de Miguel Gomes, em workshop ministrado em Curitiba, dentro do projeto "Ficção Viva", em 2013. palavras cálidas e mimosas... (ASSIS, 1997, p. 56 apud DUNKER, 2006, p. 33)

Ao comentar a passagem de Machado de Assis, Dunker diz:

$\mathrm{O}$ ato atordoa seus agentes pela interrupção que produz do gesto. Há uma descontinuidade - o sujeito fica preso a esse instante ritmicamente descrito por Machado. O ato marca de forma clara e irreversível um antes e um depois. (DUNKER, 2006, p. 34)

Ato-descontinuidade. Não é possível prever. Não é possível planejar a ruptura necessária (com cadeias anteriores e um modo lógico de organização) no momento da criação. Um novo tempo e espaço que implica a relação com o set, direção, si mesmo - exige o salto no vazio. Nova produção a partir de uma experiência que põe em xeque a segurança já adquirida, o imaginário já constituído - e qualquer relação de domínio. Em psicanálise, o conceito de ato está ligado a algo que "não se queria fazer", uma falha (ato falho); uma encenação (acting out), mas como se fosse outro a fazer; um "não estava em mim, não me reconheço no que fiz (...) não era isso que eu queria fazer" (DUNKER, 2006, p. 33). Este algo que se dá a revelia - como se o sujeito não escolhesse (não foi ele que fez): é neste sentido que o ato é não antecipável. Quando se vê, já fez. O estado cênico tem a ver com isto também. Mas seria hipocrisia deixar o ator no abismo de seus processos; sem orientação. A orientação é: o enlaçamento verbo-corpo; tecer linguagem para constituir experiência, quando algo ultrapassa esta linguagem e 
é Real (indizível); a perspectiva de acionar as fantasias, eleger focos, escrever para fazer voltar ecos. Ainda assim, algo que não é em linha reta; é preciso deslize, escorregadela; erros, acasos e incerteza; o passo torto, manco. É preciso um jogo de entortamentos, para se segurar na tessitura da poética atoral.

\section{Conclusão}

É possível, para além dos efeitos advindos de uma estética do excesso (de afeto) ou da despersonalização; pra além da caricatura, deboche, citação e artificialidade caros a certos filmes; para além do desenho-vivo posto como estrutural; imprimir, em se tratando da atuação naturalista, uma figuração do "objeto a", através de um "pequeno insignificante". Além disto, é possível investir na evocação da ação a posteriori, quando o corpo produz nas entrelinhas das palavras, e na cotidianidade, que se apresenta como vácuo de interpretação, pois registro específico de determinada estética que independe do universo diegético. É possível também investir no próprio contexto de jogo e nos materiais de substituição para evocar a presença de um espaço "dentro" que, paradoxalmente, fica "fora" do discurso fílmico - preservando um lugar de fratura. É possível provocar a anamorfose no olhar do espectador quando se preserva estes espaços e é preciso lutar por eles para que, na poética fílmica contemporânea que demanda o naturalismo da atuação do ator, este possa encontrar o seu lugar.
Recebido em: 19/01/2017

Aceito em: 04/04/2017

\section{Referências Bibliográficas}

BONDIA, Jorge Larrosa. Notas sobre a experiência e o saber de experiência. Rio de Janeiro, Revista Brasileira de Educação, n. 19, p 20-28, 2002.

BRESSON, Roberto. Notas Sobre EI Cinematógrafo. México, Ediciones Era, 1979.

DUNKER, Christian. A Imagem entre - Olho e o Olhar. In: Sobre Arte e Psicanálise. São Paulo, Ed. Escuta, 2006, v.1, p 14-29.

HAGEN, Uta. Técnica para o Ator: A Arte da Interpretação Ética. São Paulo, Ed. Martins Fontes, 2007.

KUSNET, Eugenio. Ator e Método. São Paulo: Hucitec, 1992.

LACAN, Jacques (1960). Subversão do sujeito e dialética do desejo. In: Escritos. Rio de Janeiro: Jorge Zahar Editor, 1998.

LACAN, Jacques (1961-1962). O Seminário, Livro 9: A Identificação. Recife: Centro de Estudos Freudianos, 2003. Edição para uso interno, sem fins comerciais.

LACAN, Jacques (1962-1963). O Seminário, Livro 10: A Angústia. Rio de Janeiro: Jorge Zahar, 2005. 
LACAN, Jacques. Conferência A Terceira (1974). In: Cadernos Lacan. Porto Alegre: APPOA, 2002. v. 2.

LETERRIER, François. Robert Bresson l'insaisissable, In: Cahiers du cinema, n 66, Natal de 1957.

MONOD, Roland. Em travaillant avec Robert Bresson, In: Cahiers du cinéma, n 64, novembro de 1956.

NACCACHE, Jacqueline. O Ator de Cinema. Lisboa, ed. Texto \& Grafia, 2012. 